\title{
ANALISIS POTENSI NILAI EKONOMI SAMPAH PERUMAHAN KOTA PONTIANAK
}

Atni Asdiantri $^{1}$ ) Yulisa Fitrianingsih ${ }^{1)}$ Laili Fitria ${ }^{1)}$

1) Program Studi Teknik Lingkungan Jurusan Teknik Sipil Fakultas Teknik Universitas Tanjungpura, Pontianak Email : atniasdiantrii@gmail.com

\begin{abstract}
ABSTRAK
Pengelolaan sampah di Kota Pontianak masih menerapkan paradigma lama dimana sistem yang dilakukan adalah pengangkutan, pengumpulan, dan pembuangan di Tempat Pemrosesan Akhir (TPA). Penerapan paradigma lama tersebut membuat penanganan sampah yang dilakukan kurang efisien. Sampah yang diangkut, dikumpulkan dan dibuang di TPA masih memiliki nilai ekonomi. Tujuan dari penelitian ini yaitu menganalisis timbulan dan komposisi sampah perumahan di Kota Pontianak serta menganalisis potensi dan nilai ekonomi sampah perumahan di Kota Pontianak. Sampling timbulan dan komposisi sampah dilakukan selama 8 (delapan) hari berturut-turut sesuai dengan SNI 19-3964-1994 tentang metode pengambilan dan pengukuran contoh timbulan dan komposisi sampah perkotaan. Hasil berat sampah dari tiap komposisi sampah kemudian dikonversi dengan nilai ekonomi sampah yang ditentukan oleh Bank Sampah Rosella Kota Pontianak dan sampah organik yang diolah menjadi kompos didasarkan pada nilai harga kompos yang ada di Jalan Sei Landak Timur Perumnas 4 Kota Pontianak. Total timbulan sampah perumahan Kota Pontianak sebesar $126895,82 \mathrm{~kg} /$ hari atau 126,89 ton/hari. Komposisi sampah perumahan Kota Pontianak yang memiliki persentase sampah tertinggi yaitu sampah organik dengan jenis sampah organik lainnya dengan presentase sebesar 63,44\% dan sampah anorganik tertinggi dengan jenis sampah anorganik lainnya dengan persentase sebesar $20,43 \%$. Persentase sampah organik jenis sampah kardus $1,21 \%$, koran $0,54 \%$, kertas putih $0,81 \%$, dan kertas kulit 3,12\%. Persentase sampah anorganik jenis sampah botol 3,37\%, gelas plastik 1,41\%, kaleng $1,11 \%$, botol dan plastik berwarna 2,25\%. Persentase B3 sebesar 2,31\%. Potensi nilai ekonomi sampah perumahan Kota Pontianak sebesar Rp163.632.081/hari. Potensi nilai ekonomi sampah tahun 2016 sebesar Rp59.725.709.457/tahun.
\end{abstract}

Kata Kunci : Sampah, Potensi Nilai Ekonomi Sampah, Sampah Perumahan.

\begin{abstract}
Municipal solid waste management in Pontianak still apply the old paradigm where the system consists of three steps, transporting, collecting, and discharging to the landfill site. The application of the old paradigm has made the municipal solid waste management done inefficient. Solid waste which were transported, collected, and discharged actually still have their own economic value. The aims of this research are to analyze the total and the composition of residential solid waste in Pontianak and to analyze the economic value potential from the residential solid waste in Pontianak. Sampling of the total and the composition of the solid waste was done in 8 (eight) consecutive days in accordance with SNI 19-3964-1994 about methods of collect and measure the sample of total and composition of municipal solid waste. The weight of the solid waste from each composition then converted by the economic value determined by the Rosella Waste Bank, Pontianak and the economic value of compost from organic waste based on market value at Perumnas 4 Sei Landak Timur street, Pontianak. The total of residential solid waste in Pontianak is up to $126895,82 \mathrm{~kg} /$ hari atau 126,89 ton/hari. The composition of residental waste which has the
\end{abstract}


highest percentage is organic waste with others type with percentage of $63,44 \%$, meanwhile the highest anorganic waste is the others type with percentage of $20,43 \%$. The percentage of organic waste, for cardboards $1,21 \%$, newspapers $0,54 \%$, white papers $0,81 \%$, and parchment $3,12 \%$. The percentage of inorganic waste, for bottles $3,37 \%$, plastic cups $1,41 \%$, cans $1,11 \%$, and colored plastic bottles 2,25\%. The percentage of toxic hazardous materials is 2,31\%. The potential economic value from residential solid waste in Pontianak is $R p 163.632 .081$ per day. The potential economic value from residential solid waste in Pontianak in 2016 amounting to $R p$ 59.725.709.457 per year.

Keywords: Solid Waste, Potential Economic Value of Solid Waste, Residential Solid Waste.

\section{PENDAHULUAN}

Jumlah penduduk yang semakin meningkat akan berpengaruh pada sampah yang dihasilkan. Sampah yang dihasilkan tanpa dikelola dengan baik dapat menimbulkan masalah. Hal ini mengakibatkan sampah yang dihasilkan tidak seimbang dengan sampah yang dikelola. Pemerintah telah melakukan berbagai usaha untuk mengatasi masalah sampah. Berdasarkan Kota Pontianak Dalam Angka 2015, Kota Pontianak merupakan salah satu kota besar yang memiliki luas wilayah $107,82 \mathrm{~km}^{2}$. Penduduk Kota Pontianak mencapai 652.325 jiwa (Disduk Capil Kota Pontianak, 2015). Pengelolaan sampah di Kota Pontianak masih menerapkan paradigma lama, yakni pengangkutan, pengumpulan, dan pembuangan di Tempat Pemrosesan Akhir (TPA). Penerapan paradigma lama tersebut membuat penanganan sampah yang dilakukan kurang efisien. Sehingga perlu adanya penelitian untuk mengukur jumlah timbulan dan komposisi sampah agar dapat menentukan sistem pengelolaan yang tepat.

Menurut Handayani (2009), sampah memiliki nilai ekonomi yang berbeda-beda sesuai dengan komposisi sampah masing-masing dan perlakuan sebelum penjualan. Penelitian ini juga dilakukan untuk mengetahui besarnya potensi ekonomi sampah yang dapat dimanfaatkan untuk proses daur ulang sampah di Kota Pontianak. Studi ini diharapkan dapat membantu pemerintah mengetahui jumlah timbulan, komposisi sampah beserta nilai ekonomi sampah perumahan yang dihasilkan di Kota Pontianak. Nilai Ekonomi sampah dihitung berdasarkan harga sampah yang ada di Bank Sampah Rosella Kota Pontianak dan sampah organik yang diolah menjadi kompos didasarkan pada nilai harga kompos yang ada di Jalan Sei Landak Timur Perumnas 4 Kota Pontianak. Bank sampah Rosella merupakan bank sampah pertama di Kota Pontianak yang memiliki banyak nasabah aktif dan merupakan bank sampah percontohan di Kota Pontianak.

Tujuan dari penelitian ini yaitu menganalisis timbulan dan komposisi sampah perumahan di Kota Pontianak serta menganalisis potensi dan nilai ekonomi sampah perumahan di Kota Pontianak.

\section{METODOLOGI PENELITIAN}

Penelitian ini dilakukan di Kota Pontianak dengan mengambil sampel timbulan sampah di masing-masing Kecamatan. Pemilihan jumlah lokasi sampling di tiap kecamatan didasarkan pada persentase jumlah penduduk. Penelitian dilaksanakan selama 5 bulan yaitu dari bulan Maret sampai dengan Agustus 2016. Sampling timbulan dan komposisi sampah dilakukan selama 8 (delapan) hari berturut-turut sesuai dengan SNI 19-3964-1994 tentang Metode Pengambilan dan Pengukuran Contoh Timbulan dan 
Komposisi Sampah Perkotaan. Pengambilan sampel sampah akan dilakukan mulai dari hari Senin hingga hari Senin minggu berikutnya. Alat yang dipergunakan dalam pengambilan sampel timbulan sampah yaitu kantong plastik, sarung tangan, timbangan, dan masker. Langkah-langkah perhitungan nilai ekonomi sampah perumahan yaitu sampah dipisahkan anorganik dan organik, sampah perumahan dipilah menurut jenisjenis yang telah ditentukan, jumlah massa sampah yang terjual menurut jenisnya dicatat perhari, sampah dinilai kelayakannya, sampah yang layak jual ditimbang dan nilai ekonomi sampah tersebut dihitung. Berikut merupakan harga-harga yang laku dijual di Bank Sampah Rosella:

Tabel 1. Harga Bank Sampah Rosella

\begin{tabular}{|c|c|}
\hline Jenis Sampah & Harga Jual \\
\hline Kardus & $\mathrm{Rp} 1.100 / \mathrm{Kg}$ \\
\hline Koran & $\mathrm{Rp} 800 / \mathrm{Kg}$ \\
\hline Kertas Putih & $\mathrm{Rp} 800 / \mathrm{Kg}$ \\
\hline Kertas Kulit & $\mathrm{Rp} 200 / \mathrm{Kg}$ \\
\hline Botol & Rp 800/Buah \\
\hline Gelas Aqua & $\mathrm{Rp} 800 / \mathrm{Kg}$ \\
\hline Kaleng & $\mathrm{Rp} 8.000 / \mathrm{Kg}$ \\
\hline Botol Plastik Berwarna & $\mathrm{Rp} 800 / \mathrm{Kg}$ \\
\hline
\end{tabular}

Sumber: Bank Sampah Rosella, 2016

Penentuan jumlah sampel dihitung menggunakan Rumus Slovin. Bentuk analisis data yang digunakan dalam penelitian ini adalah analisis deskriptif. Analisis ini digunakan untuk memberi gambaran secara sistematis atau membuat deskripsi tentang hasil dari penelitian yang dilakukan. Analisis data yang dilakukan adalah untuk mengetahui timbulan, komposisi, dan potensi nilai ekonomi sampah. Data ini disajikan dalam bentuk tabel dan grafik sehingga dapat dilihat persentase sampah organik dan anorganik yang dihasilkan di Kota Pontianak. Analisis potensi ekonomi sampah perumahan disajikan dalam bentuk tabel yang berisikan jumlah harga jual sampah anorganik di Kota Pontianak.

\section{HASIL DAN PEMBAHASAN}

\section{- TIMBULAN SAMPAH PERUMAHAN KOTA PONTIANAK}

Kota Pontianak memiliki jumlah penduduk sebanyak 658.243 jiwa pada tahun 2015 sehingga dikategorikan sebagai Kota Besar. Kota Pontianak memiliki 6 kecamatan, terbagi menjadi 29 Kelurahan. Pengukuran terhadap timbulan sampah dilakukan dengan membagi tiap kecamatan di Kota Pontianak. Total timbulan sampah Kota Pontianak perumahan sebesar $126895,82 \mathrm{~kg} /$ hari atau 126,89 ton/hari.

\section{○ KOMPOSISI SAMPAH PERUMAHAN KOTA PONTIANAK}

Komposisi sampah perumahan dikelompokkan berdasarkan jenis sampah yang dijual di Bank Sampah Rosella Kota Pontianak dengan pembagian tiap Kecamatan. Klasifikasi 
jenis sampah digunakan untuk mengetahui nilai ekonomi sampah. Klasifikasi jenis sampah yang digunakan yaitu kardus, koran, kertas putih, kertas kulit, botol, gelas plastik, kaleng, dan botol plastik berwarna. Tambahan untuk melihat komposisi sampah yang ada di Kota Pontianak yaitu anorganik lainnya, organik lainnya, dan Bahan Berbahaya Beracun (B3). Sampah anorganik lainnya yaitu sampah yang tidak laku dijual di bank sampah Rosella seperti kantong plastik, palstik kemasan, sedotan, karung, sikat gigi, dan berbagai sampah anorganik selain yang laku dijual di Bank Sampah Rosella. Sampah organik lainnya yaitu sampah sisa-sisa makanan, dedaunan, bangkai binatang, dan sampah organik selain yang laku dijual di Bank Sampah Rosella. Hasil pengambilan sampel komposisi sampah dijelaskan dengan komposisi tiap kecamatan di Kota Pontianak.

\section{- Kecamatan Pontianak Kota}

Kecamatan Pontianak Kota memiliki jumlah penduduk sebesar 122.101 orang dengan persentase 18,55\% dari jumlah total penduduk Kota Pontianak. Dari 18,55\% didapatkan 20 jumlah rumah yang disampel. Hasil pengambilan sampel komposisi sampah untuk kecamatan Pontianak Kota dapat dilihat pada Gambar 1.

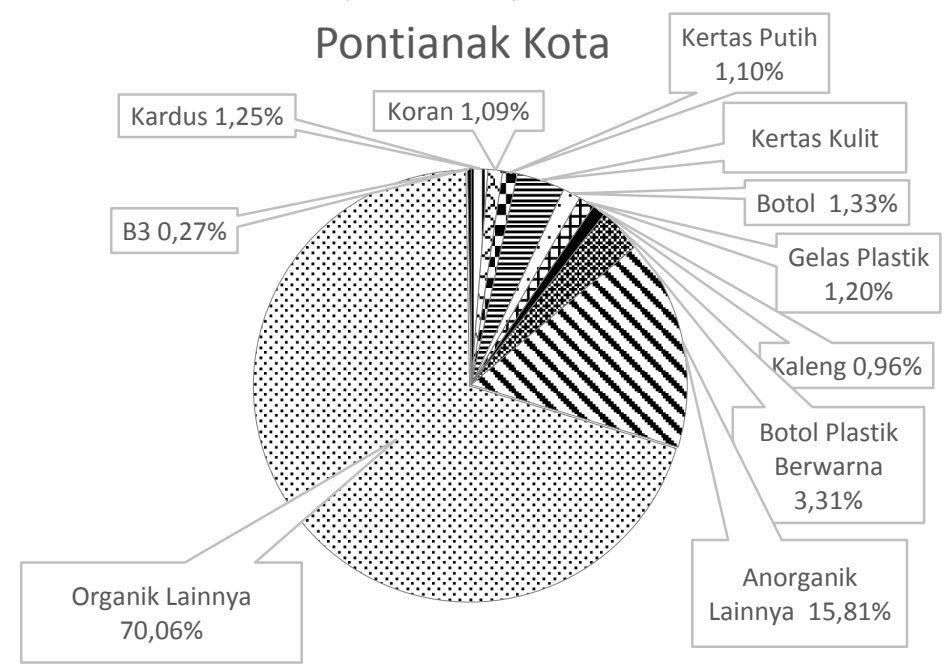

Gambar 1. Hasil Pengambilan Sampel Komposisi Sampah di Kecamatan Pontianak Kota

Sampah yang dihasilkan di Kecamatan Pontianak Kota menunjukkan bahwa persentase sampah tertinggi yaitu sampah organik, dengan jenis sampah organik lainnya dengan persentase $70,06 \%$. Sampah anorganik tertinggi yaitu dengan jenis sampah anorganik lainnya dengan persentase $15,81 \%$. Sampah organik terendah ditunjukkan pada jenis sampah koran dengan persentase 1,09\%. Sampah anorganik terendah ditunjukkan pada jenis sampah kaleng dengan persentase $0,96 \%$.

- Kecamatan Pontianak Timur

Kecamatan Pontianak Timur memiliki jumlah penduduk sebesar 99.182 orang dengan persentase $15,07 \%$ dari jumlah total penduduk kota Pontianak. Dari 15,07\% didapatkan 17 jumlah rumah yang di sampel. Hasil pengambilan sampel komposisi sampah untuk kecamatan Pontianak Timur dapat dilihat pada Gambar 2. 


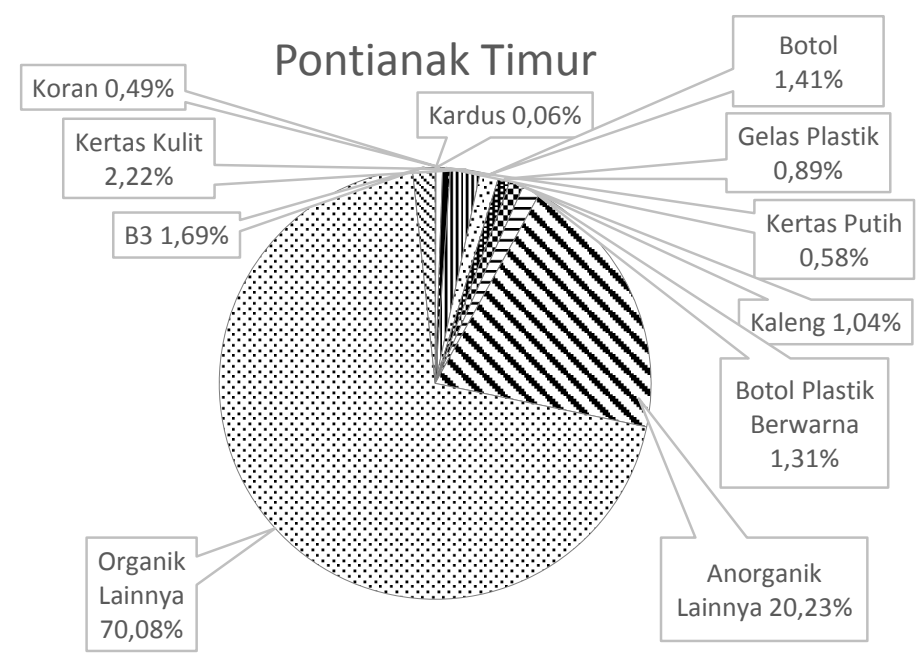

Gambar 2. Hasil Pengambilan Sampel Komposisi Sampah di Kecamatan Pontianak Timur

Sampah yang dihasilkan di Kecamatan Pontianak Timur menunjukkan bahwa persentase sampah tertinggi yaitu sampah organik, dengan jenis sampah organik lainnya dengan persentase $70,08 \%$. Sampah anorganik tertinggi yaitu dengan jenis sampah anorganik lainnya dengan persentase $20,23 \%$. Sampah organik terendah ditunjukkan pada jenis sampah kardus dengan persentase 0,06\%. Sampah anorganik terendah ditunjukkan pada jenis sampah gelas plastik dengan persentase $0,89 \%$.

- Kecamatan Pontianak Utara

Kecamatan Pontianak Utara memiliki jumlah penduduk sebesar 147.771 orang dengan persentase $22,45 \%$ dari jumlah total penduduk kota Pontianak. Dari 22,45\% didapatkan 25 jumlah rumah yang di sampel. Hasil pengambilan sampel komposisi sampah untuk kecamatan Pontianak Utara dapat dilihat pada Gambar 3.

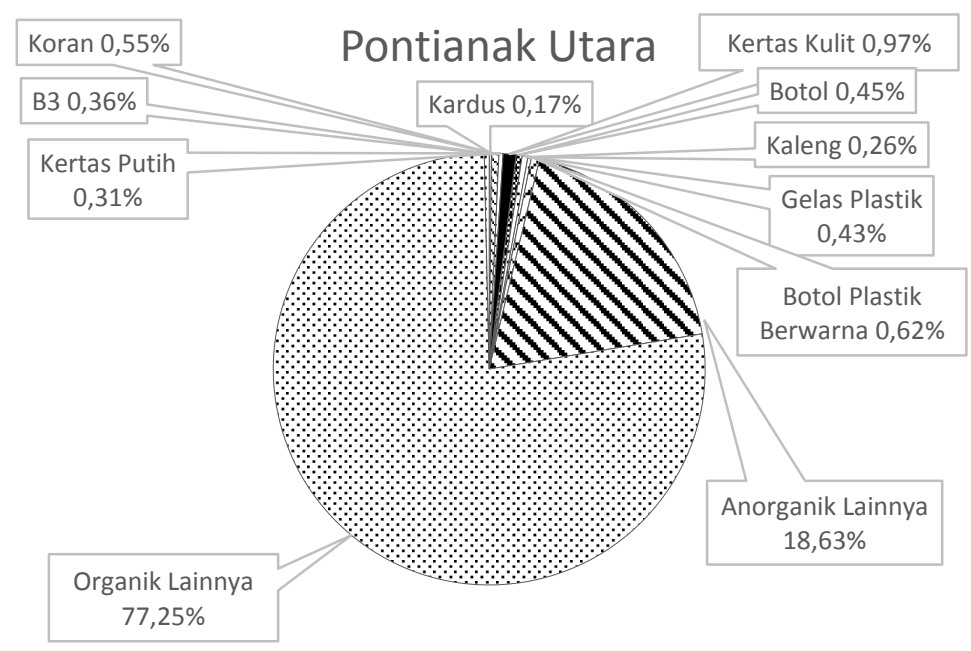

Gambar 3. Hasil Pengambilan Sampel Komposisi Sampah di Kecamatan Pontianak Utara

Sampah yang dihasilkan di Kecamatan Pontianak Utara menunjukkan bahwa persentase sampah tertinggi yaitu sampah organik, dengan jenis sampah organik lainnya dengan persentase $77,25 \%$. Sampah anorganik tertinggi yaitu dengan jenis sampah 
anorganik lainnya dengan persentase $18,63 \%$. Sampah organik terendah ditunjukkan pada jenis sampah kardus dengan persentase 0,17\%. Sampah anorganik terendah ditunjukkan pada jenis sampah kaleng dengan persentase $0,26 \%$.

- Kecamatan Pontianak Barat

Kecamatan Pontianak Utara memiliki jumlah penduduk sebesar 147.582 orang dengan persentase 22,42\% dari jumlah total penduduk kota Pontianak. Dari 22,42\% didapatkan 25 jumlah rumah yang di sampel. Hasil pengambilan sampel komposisi sampah untuk kecamatan Pontianak Barat dapat dilihat pada Gambar 4.

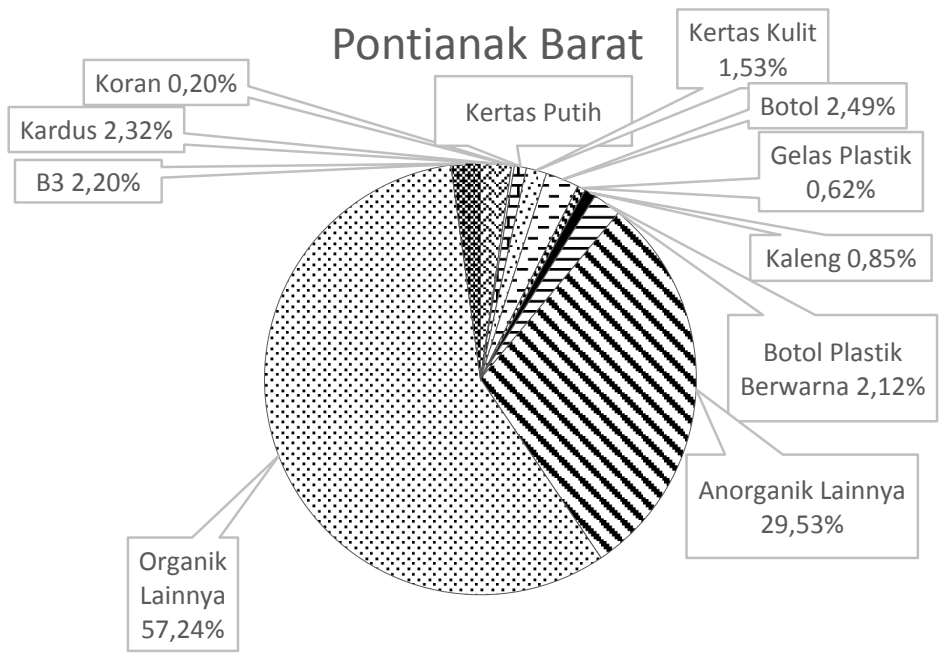

Gambar 4. Hasil Pengambilan Sampel Komposisi Sampah di Kecamatan Pontianak Barat

Sampah yang dihasilkan di Kecamatan Pontianak Barat menunjukkan bahwa persentase sampah tertinggi yaitu sampah organik, dengan jenis sampah organik lainnya dengan persentase $57,24 \%$. Sampah anorganik tertinggi yaitu dengan jenis sampah anorganik lainnya dengan persentase $29,53 \%$. Sampah organik terendah ditunjukkan pada jenis sampah koran dengan persentase 0,20\%. Sampah anorganik terendah ditunjukkan pada jenis sampah gelas plastik dengan persentase $0,62 \%$.

- Kecamatan Pontianak Selatan

Kecamatan Pontianak Selatan memiliki jumlah penduduk sebesar 96.780 orang dengan persentase $14,70 \%$ dari jumlah total penduduk kota Pontianak. Dari $14,70 \%$ didapatkan 16 jumlah rumah yang di sampel. Hasil pengambilan sampel komposisi sampah untuk kecamatan Pontianak Selatan dapat dilihat pada Gambar 5. 


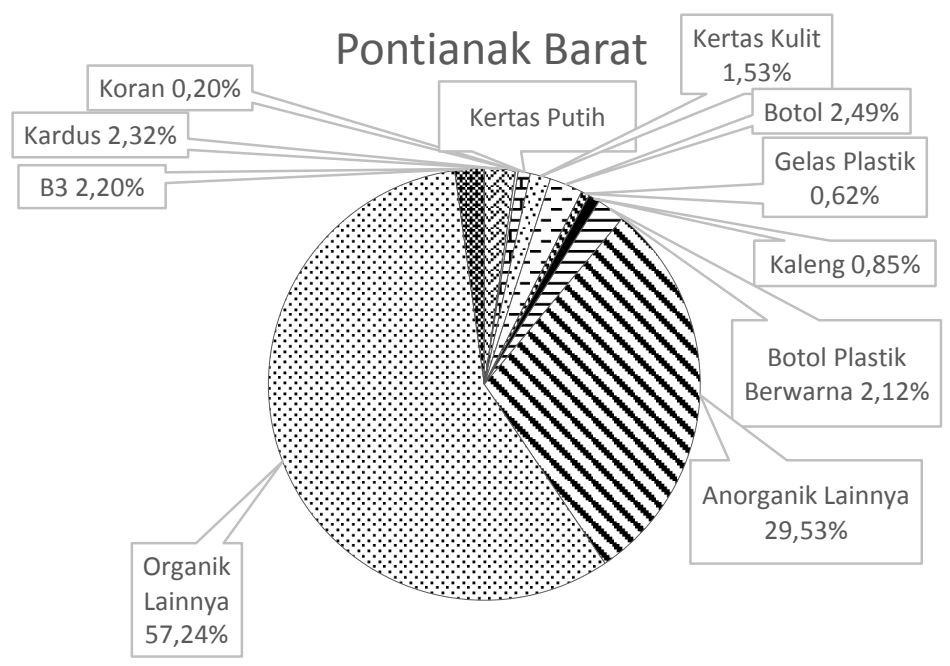

Gambar 5. Hasil Pengambilan Sampel Komposisi Sampah di Kecamatan Pontianak Selatan

Sampah yang dihasilkan di Kecamatan Pontianak Selatan menunjukkan bahwa persentase sampah tertinggi yaitu sampah organik, dengan jenis sampah organik lainnya dengan persentase $49,24 \%$. Sampah anorganik tertinggi yaitu dengan jenis sampah anorganik lainnya dengan persentase $21,41 \%$. Sampah organik terendah ditunjukkan pada jenis sampah koran dengan persentase 0,00\%. Sampah anorganik terendah ditunjukkan pada jenis sampah kaleng dengan persentase $2,08 \%$.

- Kecamatan Pontianak Tenggara

Kecamatan Pontianak Tenggara memiliki jumlah penduduk sebesar 44.827 orang dengan persentase $6,81 \%$ dari jumlah total penduduk kota Pontianak. Dari 6,81\% didapatkan 7 jumlah rumah yang di sampel. Hasil pengambilan sampel komposisi sampah untuk kecamatan Pontianak Tenggara dapat dilihat pada Gambar 6.

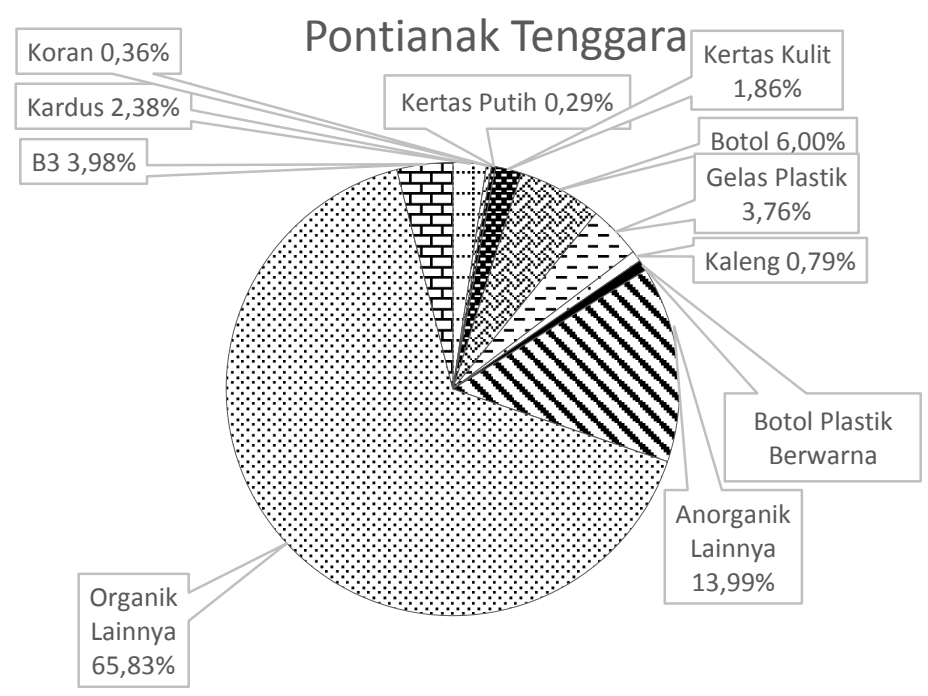

Gambar 6. Hasil Pengambilan Sampel Komposisi Sampah di Kecamatan Pontianak Tenggara 
Sampah yang dihasilkan di Kecamatan Pontianak Tenggara menunjukkan bahwa persentase sampah tertinggi yaitu sampah organik dengan jenis sampah organik lainnya dengan persentase $65,83 \%$. Sampah anorganik tertinggi yaitu dengan jenis sampah anorganik lainnya dengan persentase $13,99 \%$. Sampah organik terendah ditunjukkan pada jenis sampah botol plastik berwarna dengan persentase $0,06 \%$. Sampah anorganik terendah ditunjukkan pada jenis sampah kertas putih dengan persentase $0,29 \%$.

- Rekapitulasi Komposisi Sampah Perumahan Kota Pontianak

Komposisi sampah di suatu kota akan mempengaruhi potensi nilai ekonomi sampah. Hasil pengambilan sampel komposisi sampah di Kota Pontianak dapat dilihat pada Gambar 7.

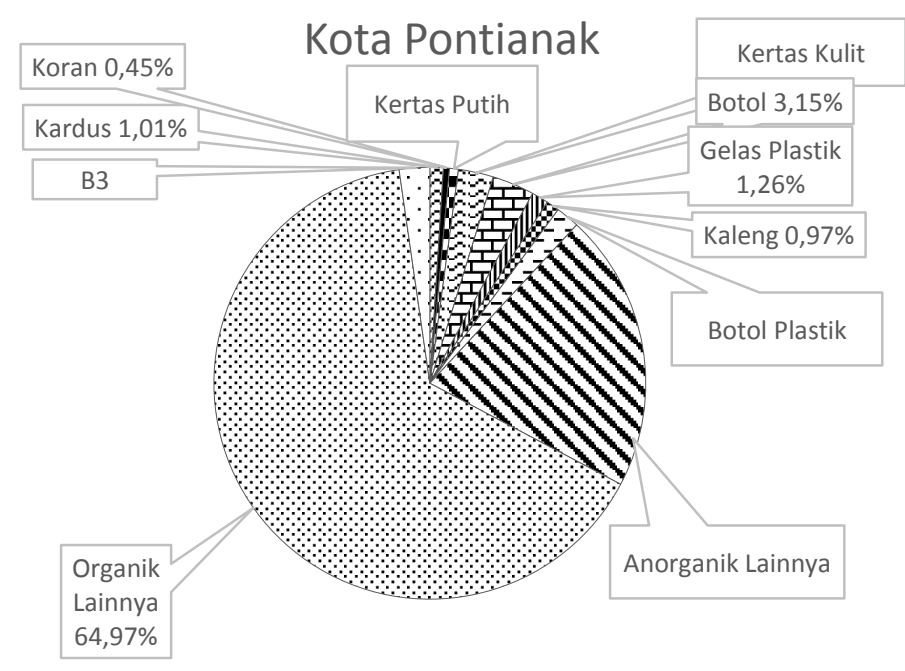

Gambar 7. Hasil Pengambilan Sampel Komposisi Sampah di Kota Pontianak

Hasil pengambilan sampel 6 Kecamatan, didapatkan komposisi sampah Kota Pontianak menunjukkan bahwa persentase sampah tertinggi yaitu sampah organik dengan jenis sampah organik lainnya dengan persentase $63,44 \%$. Sampah anorganik tertinggi yaitu dengan jenis sampah anorganik lainnya dengan persentase $20,43 \%$. Sampah organik terendah ditunjukkan pada jenis sampah koran dengan persentase $0,54 \%$. Sampah anorganik terendah ditunjukkan pada jenis sampah kaleng dengan persentase $1,11 \%$.

\section{- ANALISIS POTENSI NILAI EKONOMI SAMPAH PERUMAHAN DI KOTA PONTIANAK}

Analisis nilai ekonomi sampah yang dihasilkan berdasarkan harga sampah bank sampah Rosella dan sampah organik lainnya yang bernilai jual ketika menjadi kompos. Jenis sampah yang dijual oleh Bank Sampah Rosella merupakan jenis sampah yang laku dijual di pengepul-pengepul di Kota Pontianak. Berikut merupakan rekapitulasi semua jenis sampah yang laku di jual beserta analisis nilai ekonomi sampah Kota Pontianak. 
Tabel 2. Nilai Ekonomi Sampah Perumahan Kota Pontianak Berdasarkan Jenis

\begin{tabular}{|c|l|c|rr|rr|}
\hline No & \multicolumn{1}{|c|}{ Jenis Sampah } & $\begin{array}{c}\text { Timbulan Sampah } \\
\text { (Kg/Hari) }\end{array}$ & \multicolumn{2}{|c|}{ Harga/Kg } & \multicolumn{2}{|c|}{$\begin{array}{c}\text { Nilai Ekonomi } \\
\text { Sampah }\end{array}$} \\
\hline 1 & Kardus & 1277,59 & $\mathrm{Rp}$ & 1.100 & $\mathrm{Rp}$ & 1.405 .344 \\
\hline 2 & Koran & 569,25 & $\mathrm{Rp}$ & 800 & $\mathrm{Rp}$ & 455.402 \\
\hline 3 & Kertas Putih & 841,80 & $\mathrm{Rp}$ & 800 & $\mathrm{Rp}$ & 673.436 \\
\hline 4 & Kertas Kulit & 3336,61 & $\mathrm{Rp}$ & 200 & $\mathrm{Rp}$ & 667.322 \\
\hline 5 & Botol & 3998,87 & $\mathrm{Rp}$ & 800 & $\mathrm{Rp}$ & 3.199 .100 \\
\hline 6 & Gelas Plastik & 1596,61 & $\mathrm{Rp}$ & 800 & $\mathrm{Rp}$ & 1.277 .292 \\
\hline 7 & Kaleng & 1236,42 & $\mathrm{Rp}$ & 8.000 & $\mathrm{Rp}$ & 9.891 .336 \\
\hline 8 & Botol Plastik Berwarna & 2240,59 & $\mathrm{Rp}$ & 800 & $\mathrm{Rp}$ & 1.792 .469 \\
\hline 9 & Organik Lainnya & 57708,15 & $\mathrm{Rp}$ & 2.500 & $\mathrm{Rp}$ & 144.270 .380 \\
\hline
\end{tabular}

Acuan yang digunakan untuk menghitung nilai ekonomi sampah organik lainnya diambil dari suatu Tempat Penampungan Sementara (TPS) yang ada di Jalan Sei Landak Timur Perumnas 4 Kota Pontianak. TPS Perum 4 melakukan pengolahan sampah organik sebesar $200 \mathrm{Kg}$ dan kompos yang dihasilkan sebanyak $140 \mathrm{Kg}$. Harga jual kompos tersebut $1 \mathrm{Kg}$ sebesar Rp 2.500. Dari data tersebut didapatkan hasil kompos sebesar $57708,15 \mathrm{Kg}$ dari total sampah anorganik sebesar 82440,22 kg.

Dari tabel di atas menunjukkan bahwa nilai ekonomi yang dihasilkan paling besar merupakan jenis sampah organik lainnya dengan timbulan sebesar 57708,15 Kg dengan nilai ekonomi sebesar Rp 144.270.380. Nilai ekonomi yang paling rendah yaitu terdapat pada jenis sampah koran. Jenis sampah koran menghasilkan sebesar Rp 455.402/hari dengan timbulan juga paling rendah sebesar $569,25 \mathrm{~kg} / \mathrm{hari}$. Potensi yang dihasilkan di Kota Pontianak untuk Tahun 2016 dapat dilihat pada Tabel 3.

Tabel 3. Potensi Nilai Ekonomi Sampah Kota Pontianak Tahun 2016

\begin{tabular}{|l|lr|}
\hline \multicolumn{1}{|c|}{ Jenis Sampah } & \multicolumn{2}{c|}{ Nilai Potensi Sampah } \\
\hline Kardus & $\mathrm{Rp}$ & 512.950 .672 \\
\hline Koran & $\mathrm{Rp}$ & 166.221 .784 \\
\hline Kertas Putih & $\mathrm{Rp}$ & 245.804 .197 \\
\hline Kertas Kulit & $\mathrm{Rp}$ & 243.572 .354 \\
\hline Botol & $\mathrm{Rp}$ & 1.167 .671 .499 \\
\hline Gelas Plastik & $\mathrm{Rp}$ & 466.211 .450 \\
\hline Kaleng & $\mathrm{Rp}$ & 3.610 .337 .611 \\
\hline Botol Plastik Berwarna & $\mathrm{Rp}$ & 654.251 .232 \\
\hline Organik Lainnya & $\mathrm{Rp}$ & 52.658 .688 .659 \\
\hline Total & $\mathrm{Rp}$ & $\mathbf{5 9 . 7 2 5 . 7 0 9 . 4 5 7}$ \\
\hline
\end{tabular}

Tabel diatas menujukkan potensi nilai ekonomi sampah Kota Pontianak tahun 2016 sebesar Rp 59.725.709.457 untuk 9 jenis sampah berdasarkan sampah yang laku dijual di Bank sampah Rosella dan kompos di Perum 4. Tabel diatas menunjukkan timbulan sampah organik lainnya yang diolah menjadi kompos memiliki nilai ekonomi yang tinggi dibandingkan 8 jenis sampah lainnya. 


\section{KESIMPULAN}

Berdasarkan penelitian maka dapat disimpulkan bahwa:

1. Total timbulan sampah perumahan Kota Pontianak sebesar $126895,82 \mathrm{~kg} / \mathrm{hari}$ atau 126,89 ton/hari. Komposisi sampah perumahan Kota Pontianak persentase sampah tertinggi yaitu sampah organik dengan jenis sampah organik lainnya dengan presentase sebesar $63,44 \%$ dan sampah anorganik tertinggi dengan jenis sampah anorganik lainnya dengan persentase sebesar $20,43 \%$. Persentase sampah organik jenis sampah kardus $1,21 \%$, koran $0,54 \%$, kertas putih $0,81 \%$, dan kertas kulit 3,12\%. Persentase sampah anorganik jenis sampah botol 3,37\%, gelas plastik $1,41 \%$, kaleng $1,11 \%$, botol dan plastik berwarna $2,25 \%$. Persentase B3 sebesar $2,31 \%$.

2. Nilai ekonomi sampah perumahan Kota Pontianak sebesar Rp163.632.081/hari. Potensi nilai ekonomi sampah perumahan Kota Pontianak pada tahun 2016 sebesar Rp59.725.709.457/tahun.

\section{UCAPAN TERIMA KASIH}

Penelitian ini merupakan bagian dari penelitian "Analisis Dampak Pertumbuhan Penduduk Kota Pontianak terhadap Kapasitas Lahan dan Masa Pakai Tempat Pemrosesan Akhir (TPA) Batu Layang Kota Pontianak" oleh Laili Fitria, ST, MT, Ketua Kelompok Bidang Keahlian Teknologi dan Rekayasa Lingkungan, Program Studi Teknik Lingkungan Fakultas Teknik UNTAN. Didanai dari DIPA Perwakilan BKKBN Provinsi Kalimantan Barat Tahun 2016.

\section{DAFTAR PUSTAKA}

Badan Standarisasi Nasional. 1994. Tata Cara Pengelolaan Sampah di Permukiman. SNI 19-3242-1994. LPMB. Bandung. 